\title{
Gastrointestinal hormones in short bowel syndrome. Peptide YY may be the 'colonic brake' to gastric emptying
}

\author{
J M D Nightingale, M A Kamm, J R M van der Sijp, M A Ghatei, S R Bloom, \\ J E Lennard-Jones
}

\begin{abstract}
Background-Short bowel patients with a jejunostomy have large volume stomal outputs, which may in part be due to rapid gastric emptying of liquid. Short bowel patients with a preserved colon do not have such a high stool output and gastric emptying of liquid is normal.

Aims-To determine if differences in the gastric emptying rate between short bowel patients with and without a colon can be related to gastrointestinal hormone changes after a meal.

Subjects-Seven short bowel patients with no remaining colon (jejunal length 30$160 \mathrm{~cm}$ ) and six with jejunum in continuity with a colon (jejunal length $25-75 \mathrm{~cm}$ ), and 12 normal subjects.

Methods-The subjects all consumed a 640 kcal meal; blood samples were taken for 180 minutes for measurement of gastrointestinal hormones.

Results-Patients with a colon had high fasting peptide YY values (median 71 $\mathrm{pmol} / 1$ with a colon; $11 \mathrm{pmol} / \mathrm{h}$ normal subjects, $p<0.005$ ) with a normal postprandial rise, but those without a colon had a low fasting (median $7 \mathrm{pmol} / 1$, $p=0.076)$ and a reduced postprandial peptide YY response $(p<0 \cdot 050)$. Motilin values were high in some patients without a colon. In both patient groups fasting and postprandial gastrin and cholecystokinin values were high while neurotensin values were low. There were no differences between patient groups and normal subjects in enteroglucagon, pancreatic polypeptide, or somatostatin values.

Conclusions-Low peptide YY values in short bowel patients without a colon may cause rapid gastric emptying of liquid. High values of peptide $Y Y$ in short bowel patients with a retained colon may slow gastric emptying of liquid and contribute to the 'colonic brake'.

(Gut 1996; 39: 267-272)
\end{abstract}

Keywords: short bowel syndrome, peptide hormones, peptide YY, satiety.

Patients with a short remaining length of small intestine divide into two common clinical groups: those with a jejunostomy and those with jejunum in continuity with a colon. ${ }^{1}$ Both patient groups have problems with nutrient absorption; jejunostomy patients have additional major problems in maintaining fluid balance as they lose large volumes of water, sodium, and magnesium from their stoma. ${ }^{2}$ Some of the jejunostomy output is due to a loss of the normal daily secretions, produced in response to food ${ }^{2}$; some may be due to rapid gastric emptying of liquid, ${ }^{3}$ and some due to increased gastrointestinal secretions, such as gastric acid. ${ }^{4}$

In short bowel patients with and without a colon, the head of the liquid phase of a meal travels more rapidly from the stomach to the stoma or colon than in normal subjects. ${ }^{3}$ Following this initial rapid transit, gastric emptying of liquid in those with a colon becomes normal, while in those without a colon it remains fast. ${ }^{3}$ This finding suggests that the arrival of liquid in the colon, by a neural or humoral mechanism, is activating a 'colonic brake' that slows subsequent gastric emptying.

To determine if there may be a hormonal contribution to differences in gastric emptying rate and gastrointestinal secretions between short bowel patients with and without a colon, we have measured plasma gastrointestinal hormone values after a meal in such patients and in normal subjects.

\section{Methods}

\section{NORMAL SUBJECTS}

Twelve normal healthy volunteers (eight women and four men) with a mean age of 33 years (range 19-53) and taking no medications were studied. None had gastrointestinal symptoms or previous abdominal surgery.

\section{PATIENTS (TABLE I)}

All patients had had a previous resection of their ileum and part of their jejunum. The patients were clinically stable and well when studied at a median time of 48 months (range 3-181 months) after their last intestinal resection. All were maintaining a stable nutritional, fluid, and electrolyte status and all were taking an unrestricted oral diet. All the patients, except patient $J$, were well nourished and had a body mass index within the normal range. All patients with previous inflammatory bowel disease had no evidence of current active disease as assessed clinically, biochemically or radiologically. No patient had had gastric surgery. Bowel length was measured at operation in nine and radiologically in four patients. ${ }^{5}$ 
TABLE I Patient details

\begin{tabular}{|c|c|c|c|c|c|}
\hline & $\begin{array}{l}\text { Age } \\
\text { Sex }\end{array}$ & $\begin{array}{l}\text { fejunal } \\
\text { length }(\mathrm{cm})\end{array}$ & $\begin{array}{l}\text { Original } \\
\text { cause of } \\
\text { short bowel }\end{array}$ & $\begin{array}{l}\text { Time since } \\
\text { last small bowel } \\
\text { resection (months) }\end{array}$ & $\begin{array}{l}\text { Nutritional } \\
\text { or fluid } \\
\text { supplements }\end{array}$ \\
\hline $\begin{array}{l}\text { Shor } \\
\text { A } \\
\text { B }^{\star} \\
\text { C } \\
\text { D } \\
\text { E } \\
\text { F } \\
\text { G }\end{array}$ & $\begin{array}{l}\text { owel wi } \\
32 \mathrm{~F} \\
32 \mathrm{M} \\
36 \mathrm{~F} \\
62 \mathrm{~F} \\
61 \mathrm{M} \\
70 \mathrm{M} \\
55 \mathrm{M}\end{array}$ & $\begin{array}{c}\text { colon } \\
30 \\
50 \mathrm{x} \\
60 \\
90 \\
120 \\
130 \mathrm{x} \\
160\end{array}$ & $\begin{array}{l}\text { Crohn's disease } \\
\text { Ulcerative colitis } \\
\text { Desmoid disease } \\
\text { Irradiation } \\
\text { Crohn's disease } \\
\text { Crohn's disease } \\
\text { Crohn's disease }\end{array}$ & $\begin{array}{r}40 \\
68 \\
48 \\
3 \\
181 \\
127 \\
146\end{array}$ & $\begin{array}{l}\text { HPN } \\
\text { HPN } \\
\text { HPN } \\
\text { Oral } \\
\text { Oral } \\
\text { Oral } \\
\text { Oral }\end{array}$ \\
\hline $\begin{array}{l}\text { Shor } \\
\mathrm{H} \\
\mathrm{I}+ \\
\mathrm{J} \\
\mathrm{K} \dagger \\
\mathrm{Lf} \\
\mathrm{M} \emptyset\end{array}$ & $\begin{array}{l}\text { owel wi } \\
19 \mathrm{M} \\
25 \mathrm{M} \\
41 \mathrm{~F} \\
60 \mathrm{M} \\
58 \mathrm{~F} \\
51 \mathrm{M}\end{array}$ & $\begin{array}{l}\text { colon } \\
25 \\
25 \\
70 x \\
75 x \\
75 \\
75\end{array}$ & $\begin{array}{l}\text { Volvulus } \\
\text { Volvulus } \\
\text { Adhesions } \\
\text { Ischaemia } \\
\text { Volvulus } \\
\text { Volvulus }\end{array}$ & $\begin{array}{r}28 \\
36 \\
72 \\
147 \\
32 \\
23\end{array}$ & $\begin{array}{l}\text { HPN } \\
\text { HPN } \\
\text { Oral } \\
\text { None } \\
\text { Oral } \\
\text { None }\end{array}$ \\
\hline
\end{tabular}

Short bowel with no colon

Six patients with an end jejunostomy and one patient with a jejunorectal anastomosis were included in this group. Four of them had less than $100 \mathrm{~cm}$ of jejunum remaining, of whom three required longterm home parenteral nutrition. The other four patients required oral electrolyte or nutritional supplements to maintain fluid balance and nutritional status.

Short bowel with a colon

Six patients with most of their colon in situ were studied. Two had their jejunum anastomosed to a short length of terminal ileum (15 $\mathrm{cm}$ of ileum in patient $\mathrm{L}$, and $5 \mathrm{~cm}$ in patient $M$ ), and had a retained ileocaecal valve and whole colon, two had jejunum anastomosed to the caecum, and two jejunum anastomosed to the proximal transverse colon. Two patients, both with jejunal lengths of $25 \mathrm{~cm}$, were receiving longterm home intravenous nutrition. Two others took oral nutritional supplements and two others required no fluid or nutritional supplements.

\section{STUDY DESIGN}

Antisecretory drugs omeprazole (patient B), octreotide (patient A), and ranitidine (patients $C$ and D) were stopped five, three, and one day respectively prior to the study. The antidiarrhoeal drugs codeine or loperamide, or both, (all patients except A, B, H, and I) were stopped the evening before the study; these drugs were not stopped earlier because of potential drug withdrawal symptoms. Women were studied during the first half of the menstrual cycle.

A standardised test meal of a pancake and orange juice was chosen; total weight $415 \mathrm{~g}$, energy $640 \mathrm{kcal}$, carbohydrate $80 \mathrm{~g}$, fat $27 \mathrm{~g}$, protein $18 \mathrm{~g}$, potassium $20 \mathrm{mmol}$, sodium 6 $\mathrm{mmol}$, fibre $1 \mathrm{~g}$. After fasting from midnight the meal was eaten in the morning (about 10 am) over 10 minutes then the orange juice $(195 \mathrm{ml})$ was drunk. Time 0 is taken as the time of starting to eat the meal. Blood samples were taken at $0,15,30,45,60,90,120$, and 180 minutes for hormone assays. Nothing else was eaten or drunk for the following six hours. The patients on home parenteral nutrition had stopped their infusion at least two and a half hours before the study.

Liquid and solid gastric emptying and small bowel transit were determined during this study; the results have been published previously. ${ }^{3}$

This study was approved by the ethical committee of the City and Hackney District Health Authority and all subjects gave informed consent.

\section{HORMONE ANALYSIS}

Ten $\mathrm{ml}$ blood samples for hormone assays were taken into heparinised tubes containing 4000 kallikrein inactivator units of aprotinin $(0.2 \mathrm{ml}$ Trasylol). Plasma was separated within 15 minutes of sampling and frozen at $-20^{\circ} \mathrm{C}$ until time of assay. The plasma values of neurotensin, motilin, enteroglucagon, pancreatic polypeptide, gastrin, peptide YY, cholecystokinin, and somatostatin were all measured by radioimmunoassays. ${ }^{6-8}$ The median fasting and peak values, and the integrated response (IR) were determined for each hormone.

\section{STATISTICAL ANALYSIS}

The Mann-Whitney $U$ test was used to compare each group of patients with normal subjects at all sample times.

\section{Results}

TOLERANCE OF PROCEDURE

All normal subjects ate the meal within 10 minutes with no difficulty. Most of the short bowel patients had problems consuming the meal; patient A with no colon could not eat all of the pancake even after 20 minutes and left $80 \mathrm{~g}$. Three patients with a colon had considerable difficulty in finishing the meal: one (J) left $63 \mathrm{~g}$ after 25 minutes, two others ( $\mathrm{H}$ and I) took 12 and 20 minutes to finish the meal. No subject had any problem drinking the orange juice.

\section{PLASMA HORMONE VALUES (TABLE II)}

\section{Neurotensin}

There was a tendency for fasting and postprandial values of neurotensin to be lower in both patient groups than controls (Fig 1). In those without a colon, fasting (Fig 2) and peak neurotensin values correlated with the remaining length of jejunum (fasting: $r=0 \cdot 86$, $\mathrm{p}<0.05$, peak: $r=0.89, \mathrm{p}<0.05)$.

\section{Motilin}

Motilin values in patients without a colon were significantly higher than in normal subjects at $0,90,120$, and 180 minutes $(p<0.05)$ (Fig 3). However those, with the most rapid gastric emptying of liquid and the shortest remaining lengths of jejunum, had motilin values within the normal range. 


\section{Enteroglucagon}

Fasting and postprandial enteroglucagon values were not significantly different, in either group, from normal subjects.

TABLE II Gastrointestinal hormone results (median and range)

\begin{tabular}{|c|c|c|c|}
\hline & $\begin{array}{l}\text { Normal } \\
(n=12)\end{array}$ & $\begin{array}{l}\text { No colon } \\
(n=7)\end{array}$ & $\begin{array}{l}\text { Colon } \\
(n=6)\end{array}$ \\
\hline \multicolumn{4}{|c|}{ Neurotensin $(\mathrm{pmol} / \mathrm{l})$} \\
\hline Fasting & $\begin{array}{l}46 \\
(15-72)\end{array}$ & $\begin{array}{l}36 \\
(19-70)\end{array}$ & $\begin{array}{l}34 \\
(19-49)\end{array}$ \\
\hline Peak & $\begin{array}{l}74 \\
(29-153)\end{array}$ & $\begin{array}{l}46^{\star} \\
(24-70)\end{array}$ & $\begin{array}{l}44 \\
(32-84)\end{array}$ \\
\hline IR & $\begin{array}{l}1327 \\
(-1479-11069)\end{array}$ & $\begin{array}{l}-127 \\
(-3723-1914)\end{array}$ & $\begin{array}{l}944 \\
(-1215-3963)\end{array}$ \\
\hline \multicolumn{4}{|c|}{ Motilin (pmol/1) } \\
\hline Fasting & $\begin{array}{l}24 \\
(5-56)\end{array}$ & $\begin{array}{l}86^{\star} \\
(16-244)\end{array}$ & $\begin{array}{l}19 \\
(6-68)\end{array}$ \\
\hline Peak & $\begin{array}{l}51 \\
(6-91)\end{array}$ & $\begin{array}{l}118 \\
(19-398)\end{array}$ & $\begin{array}{l}25 \\
(17-115)\end{array}$ \\
\hline IR & $\begin{array}{l}396 \\
(-2475-4859)\end{array}$ & $\begin{array}{l}3174 \\
(-2858-18871)\end{array}$ & $\begin{array}{l}226 \\
(-1689-6944)\end{array}$ \\
\hline \multicolumn{4}{|c|}{ Enteroglucagon (pmol/1) } \\
\hline Fasting & $\begin{array}{l}40 \\
(16-84)\end{array}$ & $\begin{array}{l}30 \\
(6-84)\end{array}$ & $\begin{array}{l}40 \\
(5-162)\end{array}$ \\
\hline Peak & $\begin{array}{l}93 \\
(29-477)\end{array}$ & $\begin{array}{l}73 \\
(30-88)\end{array}$ & $\begin{array}{l}134 \\
(24-250)\end{array}$ \\
\hline IR & $\begin{array}{l}1794 \\
(-2822-45602)\end{array}$ & $\begin{array}{l}3503 \\
(-4224-4808)\end{array}$ & $\begin{array}{l}3526 \\
(-9424-20422)\end{array}$ \\
\hline \multicolumn{4}{|c|}{ Peptide $Y Y(\mathrm{pmol} / \mathrm{l})$} \\
\hline Fasting & $\begin{array}{l}11 \\
(6-59)\end{array}$ & 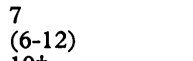 & $\begin{array}{l}71 \dagger \\
(17-179)\end{array}$ \\
\hline Peak & $\begin{array}{l}33 \\
(23-76)\end{array}$ & $\begin{array}{l}19 \ddagger \\
(11-23)\end{array}$ & $\begin{array}{l}110 \dagger \\
(58-224)\end{array}$ \\
\hline IR & $\begin{array}{l}1448 \\
(-3656-4728)\end{array}$ & $\begin{array}{l}261^{\star} \\
(-45-1309)\end{array}$ & $\begin{array}{l}3932 \\
(816-10461)\end{array}$ \\
\hline \multicolumn{4}{|c|}{ Gastrin (pmol//) } \\
\hline Fasting & $\begin{array}{l}6 \\
(4-11)\end{array}$ & $\begin{array}{l}9^{\star} \\
(5-34)\end{array}$ & $\begin{array}{l}14^{\star} \\
(5-38)\end{array}$ \\
\hline Peak & $\begin{array}{l}27 \\
(8-78)\end{array}$ & $\begin{array}{l}63 \\
(6-142)\end{array}$ & 34 \\
\hline IR & 1069 & $\begin{array}{l}2284^{\star} \\
(60-11318)\end{array}$ & $\begin{array}{l}1354 \\
(-1665-14108)\end{array}$ \\
\hline \multicolumn{4}{|c|}{ Cholecystokinin $(\mathrm{pmol} / \mathrm{l})($ no colon $\mathrm{n}=6)$} \\
\hline Fasting & $\begin{array}{l}3 \cdot 3 \\
(2 \cdot 2-4 \cdot 2)\end{array}$ & $\begin{array}{l}4 \cdot 5 \dagger \\
(3 \cdot 9-9 \cdot 4)\end{array}$ & $\begin{array}{l}4 \cdot 0^{\star} \\
(3 \cdot 7-11 \cdot 5)\end{array}$ \\
\hline Peak & $\begin{array}{l}6 \cdot 1 \\
(4 \cdot 3-10 \cdot 3)\end{array}$ & $\begin{array}{l}10 \cdot 8^{\star} \\
(3 \cdot 9-13 \cdot 6)\end{array}$ & $\begin{array}{l}9 \cdot 8 \\
(4 \cdot 4-14 \cdot 6)\end{array}$ \\
\hline IR & $\begin{array}{l}339 \\
(-65-740)\end{array}$ & $\begin{array}{l}464 \\
(-60-868)\end{array}$ & $\begin{array}{l}560 \\
(32-909)\end{array}$ \\
\hline \multicolumn{4}{|c|}{ Pancreatic polypeptide $(\mathrm{pmol} / \mathrm{l})($ no colon $\mathrm{n}=6)$} \\
\hline Fasting & $\begin{array}{l}34 \\
(12-60)\end{array}$ & $\begin{array}{l}32 \\
(17-87)\end{array}$ & $\begin{array}{l}46 \\
(32-88)\end{array}$ \\
\hline Peak & $\begin{array}{l}167 \\
(35-579)\end{array}$ & $\begin{array}{l}263 \\
(49-599)\end{array}$ & $\begin{array}{l}247 \\
(59-695)\end{array}$ \\
\hline IR & $\begin{array}{l}17052 \\
(1182-73690)\end{array}$ & $\begin{array}{l}26448 \\
(1862-66484)\end{array}$ & $\begin{array}{l}24367 \\
(-229-91010)\end{array}$ \\
\hline \multicolumn{4}{|c|}{ Somatostatin $(\mathrm{pmol} / \mathrm{l})$} \\
\hline Fasting & $\begin{array}{l}30 \\
(18-52)\end{array}$ & $\begin{array}{l}41 \\
(18-73)\end{array}$ & $\begin{array}{l}43 \\
(22-70)\end{array}$ \\
\hline Peak & $\begin{array}{l}52 \\
(41-75)\end{array}$ & $\begin{array}{l}61 \\
(31-114)\end{array}$ & $\begin{array}{l}59 \\
(41-99)\end{array}$ \\
\hline IR & $\begin{array}{l}2189 \\
(-87-4657)\end{array}$ & $\begin{array}{l}787 \\
(-3047-11781)\end{array}$ & $\begin{array}{l}1762 \\
(-2878-2384)\end{array}$ \\
\hline
\end{tabular}

IR units pmol///180 min.

${ }^{\star} \mathrm{p}<0.05, \uparrow \mathrm{p}<0.005, \neq \mathrm{p}<0.001$ compared with normal subjects.

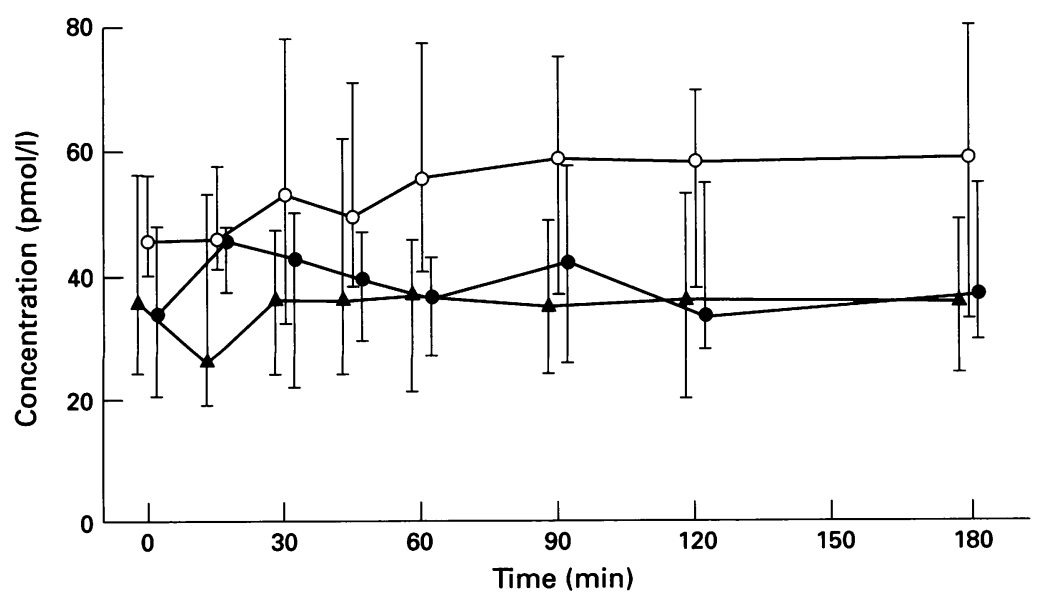

Figure 1: Graph for normal subjects $\circ$, patients with $\bullet$ and without $\mathbf{\Delta}$ a colon for neurotensin. Median and interquartile ranges shown.
Peptide YY

Patients with a colon had high fasting peptide YY values (median $71 \mathrm{pmol} / \mathrm{l}$ ) compared with normal subjects (median $11 \mathrm{pmol} / 1, \mathrm{p}<0.005$ ), and peptide $Y Y$ values were raised at all time points $(p<0.005$ except 15 minutes when $p<0.05)$. The integrated response was normal (Fig 4).

Patients without a colon had low fasting peptide $\mathrm{YY}$ values (median $7 \mathrm{pmol} / \mathrm{l}, \mathrm{p}=0.076$ ) and a reduced integrated response $(p<0.05)$ and at all time points peptide YY was less than in normal subjects $(p<0.05$ except 60 minutes when $\mathrm{p}=0.06$ ).

\section{Gastrin}

Fasting gastrin values were significantly higher in both groups of patients than in normal subjects $(p<0.05)$. In those without a colon gastrin values at 30,60 , and 180 minutes and the integrated response were also significantly higher than in normal subjects $(\mathrm{p}<0.05)$.

\section{Cholecystokinin}

In both patient groups cholecystokinin values (Fig 5) were significantly $(p<0.05)$ higher than in normal subjects at 0 and 180 minutes and additionally in those without a colon at 90 minutes.

\section{Pancreatic polypeptide}

Fasting and postprandial pancreatic polypeptide values were not significantly different, in either group, from normal subjects.

\section{Somatostatin}

Fasting and postprandial somatostatin values were not significantly different, in either group, from normal subjects.

\section{Discussion}

The plasma values of peptide $Y Y$ show the most striking difference between short bowel patients and normal subjects. In those with a preserved colon fasting and postprandial values of peptide YY were higher than normal subjects, while in those without a colon they were lower. Peptide YY, which is produced in the ileum and colon, ${ }^{7-10}$ is released when unabsorbed nutrients, especially fat, ${ }^{71}$ or bile salts $^{12}$ reach the terminal ileum and colon. High plasma concentrations of peptide YY have been reported in tropical sprue, chronic pancreatitis, ${ }^{13}$ dumping syndrome, ${ }^{14}$ and after an ileal resection leaving the colon in situ. ${ }^{15} 16$ Low values occur in patients who have had a colectomy..$^{15}$

Peptide YY slows gastric emptying. ${ }^{17} 18$ The failure of peptide YY to rise after a meal in short bowel patients without a colon, may explain why the gastric emptying rate for liquid does not slow. This rapid gastric emptying rate may be a factor in causing a large jejunostomy output. As liquid enters the colon, a rise in the already high fasting peptide YY value occurs, 
and as we have shown previously it is at this time that the gastric emptying rate of liquid returns to normal. ${ }^{3}$ Thus we suggest that peptide $\mathrm{YY}$ is responsible for this slowing of subsequent gastric emptying. Serum concentrations of peptide YY, similar to those we have measured in patients with a colon, slowed gastric emptying in normal subjects. ${ }^{18}$ It has been suggested that peptide $\mathrm{YY}$ is the major hormone responsible for the 'ileal brake'19 and now we suggest that it is also responsible for the 'colonic brake'. In addition to quickening the rate of gastric emptying, low peptide YY values in patients without a colon, may increase jejunostomy output by causing more

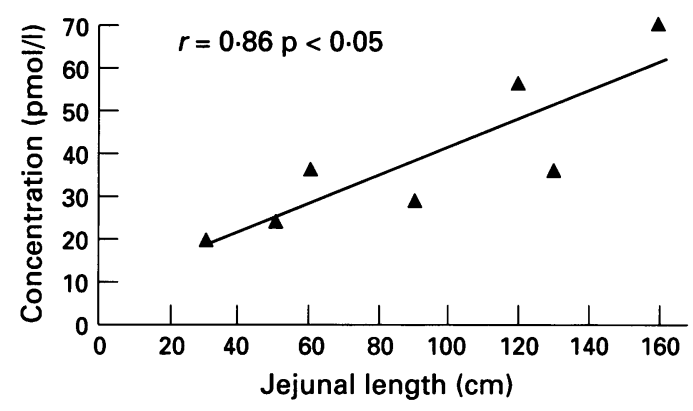

Figure 2: Graph for patients without a colon of fasting neurotensin plotted against residual jejunal length.

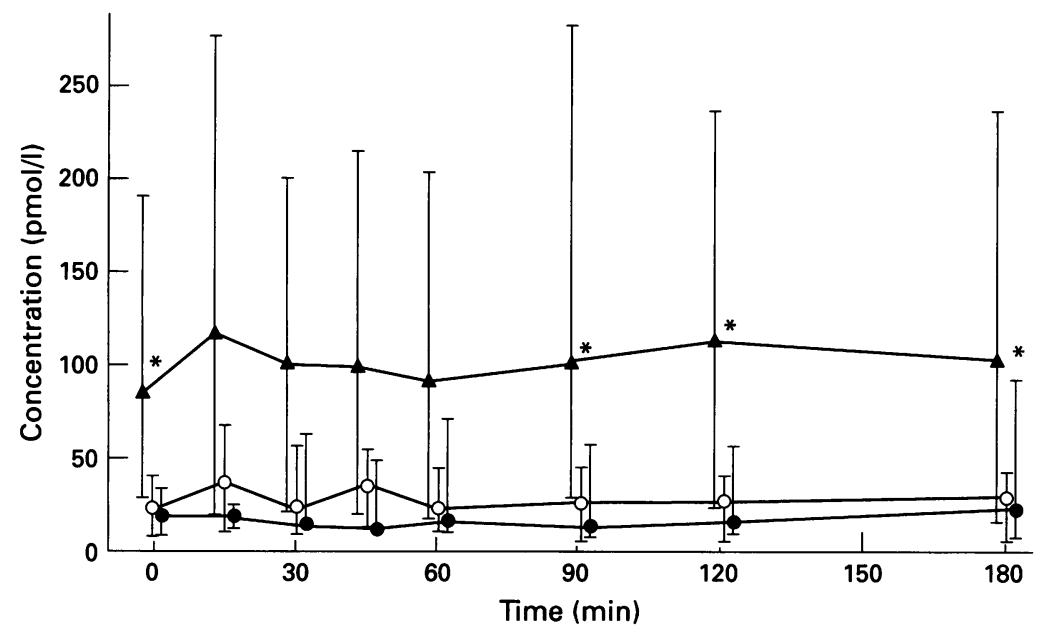

Figure 3: Graph for normal subjects $\circ$, patients with $\bullet$ and without $\mathbf{\Delta}$ a colon for motilin. Median and interquartile ranges shown. ${ }^{\star} p<0.05$.

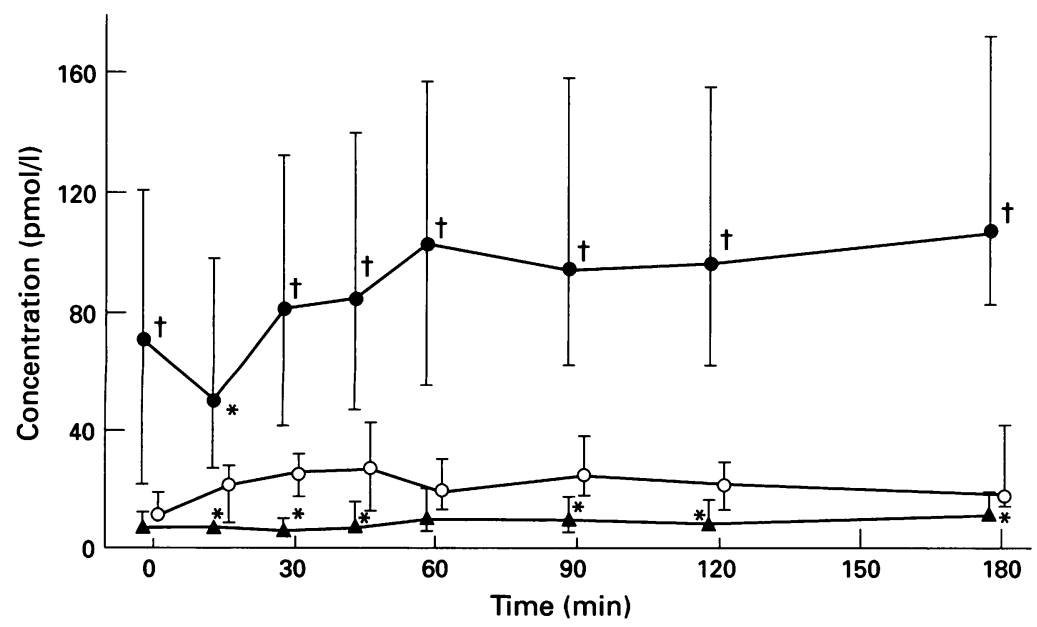

Figure 4: Graph for normal subjects 0 , patients with $\bullet$ and without $\mathbf{\Delta}$ a colon for peptide $Y Y$. Median and interquartile ranges shown. ${ }^{\star} p<0 \cdot 05,+p<0.005$. gastric acid to be secreted ${ }^{20}$ and less water and electrolyte to be absorbed by the small bowel. $^{21}$

The initial fast transit of the head of the liquid meal, in both patient groups, ${ }^{3}$ may reflect loss of neurotensin producing cells in the ileum. ${ }^{22}$ The fasting values of neurotensin, which slows gastric emptying, ${ }^{23}$ were low in both patient groups. In those without a colon fasting neurotensin values correlated with residual jejunal length. This finding may explain why those with the shortest length of remaining jejunum and the lowest neurotensin values have the most rapid rates of liquid gastric emptying. ${ }^{3}$

The values of motilin, which is produced by the upper small intestine 2425 and increases the rate of gastric emptying, ${ }^{26-28}$ were high in patients without a colon. However, low or normal motilin values were seen in those without a colon, who had the shortest remaining lengths of jejunum and the most rapid rates of liquid gastric emptying. Thus high motilin values are not responsible for rapid early gastric emptying of liquid.

Hormonal changes may affect gastrointestinal secretions and hence the volume of output from a jejunostomy. Both fasting and postprandial gastrin values were high in both patient groups. While previous drug therapy (for example, with a proton pump inhibitor or $\mathrm{H}_{2}$ antagonist) could contribute to the high gastrin values in those without a colon, this is unlikely. One patient without a colon had stopped taking $20 \mathrm{mg}$ omeprazole daily, five days before the study. This time period should have allowed serum gastrin concentrations to return to pre-treatment values. ${ }^{29}$ The two patients who had been taking ranitidine, which only increases plasma gastrin values by a small amount, ${ }^{30}$ stopped taking it at least 24 hours before the study, when the effect of ranitidine on gastric acid secretion should have ceased. ${ }^{31}$ Removal of the colon alone does not affect gastrin concentrations. ${ }^{32}$ High gastrin values probably reflect the loss of small bowel, which is a major site of gastrin catabolism. ${ }^{33}{ }^{34} \mathrm{High}$ gastrin concentrations have been reported in patients with a short bowel and a colon ${ }^{35} 36$ and now also in short bowel patients without a colon. Although the gastrin values are high it is not clear if gastric acid hypersecretion is occurring. Hypersecretion may occur shortly after a small intestinal resection, if the colon has been preserved, ${ }^{37}$ but it is unknown if gastric acid hypersecretion occurs in the long term; if it does, high gastrin values could be responsible.

Somatostatin slows gastric emptying and small bowel transit and reduces salivary, gastric, and pancreaticobiliary secretions. ${ }^{38}$ Its analogue octreotide has been used to reduce the stomal output from a jejunostomy. ${ }^{39}$ Somatostatin concentrations, at all times, were normal in both groups of patients, so there is not a somatostatin deficiency contributing to the high jejunostomy output.

Gall stones are common in patients with a short bowel with and without a colon. ${ }^{1}$ In this study no hormonal changes likely to predispose to gall stones were observed; for example 


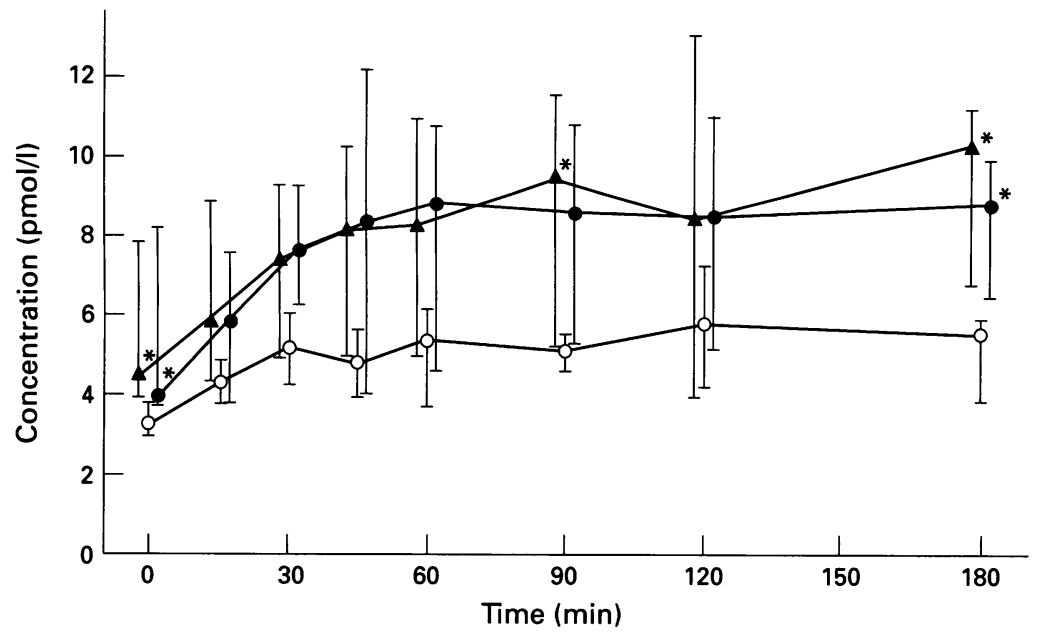

Figure 5: Graph for normal subjects $\circ$, patients with $\bullet$ and without $\mathbf{\Delta}$ a colon for cholecystokinin. Median and interquartile ranges shown. ${ }^{\star} p<0 \cdot 05$.

high pancreatic polypeptide, neurotensin or somatostatin values, or low cholecystokinin values.

Cholecystokinin may be important in causing satiety ${ }^{40-42}$ and the high concentrations observed in both groups of patient may have contributed to four of the 13 short bowel patients (three with a colon) experiencing difficulty in finishing the meal. This did not occur in any of the 12 normal subjects.

Pronounced ileal adaptation after a jejunal resection occurs in animals. In patients with a retained colon the evidence for structural ${ }^{43} 44$ and functional ${ }^{45}$ jejunal adaptation is scarce. Adaptation in patients with a jejunostomy may not occur. ${ }^{46}$ Enteroglucagon is trophic to the small bowel. ${ }^{4-50}$ In this study, neither fasting nor postprandial concentrations of enteroglucagon were raised in either group of patients. If jejunal hyperplasia occurs in patients with a retained colon it is unlikely to be due to enteroglucagon. It is interesting that, although produced by the same cells, peptide $Y Y$ and enteroglucagon values do not mirror each other. ${ }^{910}$ The low neurotensin concentrations observed could reduce jejunal adaptation..$^{51}$

In summary, in short bowel patients with and without a colon, high serum gastrin concentrations may cause gastric acid hypersecretion and high cholecystokinin values may account for satiety. Low neurotensin values, in both patient groups, may predispose to a rapid gastrointestinal transit of liquid. Low peptide YY values in short bowel patients without a colon may be partly responsible for the high volume of jejunostomy output. High peptide YY values in those with a retained colon may slow gastric emptying and so contribute to the 'colonic brake'.

We thank Ms E R Walker for giving nursing care and taking blood samples from every patient during the study. We thank Dr J D Teale of St Luke's Hospital, Guildford for performing the gastrin assays, Dr W H L Hackeng of Ysseland Hospital, Holland for performing the somatostatin assays, and Dr J Jansen for performing the cholecystokinin assays. We also thank Dr J Calam for endocrinological advice.

1 Nightingale JMD, Lennard-Jones JE, Gertner DJ, Wood SR, Bartram CI. Colonic preservation reduces the need for parenteral therapy, increases the incidence of renal stones but does not change the high prevalence of gallstones in patients with a short bowel. Gut 1992; 33: 1493-7.
2 Nightingale JMD, Lennard-Jones JE, Walker ER, Farthing MJG. Jejunal efflux in short bowel syndrome. Lancet 1990; 336: 765-8.

3 Nightingale JMD, van der Sijp JRM, Kamm MA, Walker ER, Mather SJ, Britton KE, et al. Disturbed gastric emptying in the short bowel syndrome. Evidence for a 'colonic brake'. Gut 1993; 34: 1171-6.

4 Buxton B. Small bowel resection and gastric acid hypersecretion. Gut 1974; 15: 229-38.

5 Nightingale JMD, Bartram CI, Lennard-Jones JE. Length of residual small bowel after partial resection: correlation between radiographic and surgical measurements. between radiographic and surgical

6 Bloom SR, Long RG. Radioimmunoassay of gut regulatory peptides. London: W B Saunders, 1982.

7 Adrian TE, Ferri G-L, Bacarese-Hamilton AJ, Fuessl HS, Polak JM, Bloom SR. Human distribution and release of a putative new gut hormone, Peptide YY. Gastroenterology 1985; 89: 1070-7.

8 Jansen JBMJ, Lamers CBHW. Radioimmunoassay of cholecystokinin in human tissue and plasma. Clin Chim Acta 1983; 131: 305-16.

9 Ali-Rachedi A, Varndell IM, Adrian TE, Gapp DA, Van Noorden S, Bloom SR, et al. Peptide YY (PYY) immunoreactivity is co-stored with glucagon-related immunoreactivity is co-stored with glucagon-related immunoreactants in endocrine cells of

10 Bottcher G, Sjolund K, Ekblad E, Hakanson R, Schwartz TW, Sundler F. Co-existance of peptide YY and glicentin immunoreactivity in endocrine cells of the gut. Regul Pept 1984; 8: 261-6.

11 Aponte GW, Fink AS, Meyer JH, Tatemoto K, Taylor IL. Regional distribution and release of peptide YY with fatty acids of different chain length. Am F Physiol 1985; 249: G745-50.

12 Adrian TE, Ballantyne GH, Longo WE, Bilchik AJ, Graham S, Basson MD, et al. Deoxycholate is an important releaser of peptide $\mathrm{YY}$ and enteroglucagon from the ant releaser of peptide YY and enterogl

13 Adrian TE, Savage AP, Bacarese-Hamilton AJ, Wolfe K, Besterman HS, Bloom SR. Peptide YY abnormalities in gastrointestinal diseases. Gastroenterology 1986; 90: 379-84.

14 Adrian TE, Long RG, Fuessl HS, Bloom SR. Plasma peptide YY (PYY) in dumping syndrome. Dig Dis Sci 1985; 30: $1145-8$.

15 Adrian TE, Savage AP, Fuessl HS, Wolfe K, Besterman HS, Bloom SR. Release of peptide YY (PYY) after resection of small bowel, colon or pancreas in man. Surgery tion of small bow 101 : 715-9.

16 Andrews NJ, Irving MH. Human gut hormone profiles in patients with short bowel syndrome. Dig Dis Sci 1992; 37: 729-32.

17 Allen JM, Fitzpatrick ML, Yeats JC, Darcy K, Adrian TE, Bloom SR. Effect of peptide $Y Y$ and neuropeptide $Y$ on gastric emptying in man. Digestion 1984; 30: 255-62.

18 Savage AP, Adrian TE, Carolan G, Chatterjee VK, Bloom SR. Effects of peptide YY (PYY) on mouth to caecum intestinal transit time and on the rate of gastric emptying in healthy volunteers. Gut 1987; 28: 166-70.

19 Spiller RC, Trotman IF, Adrian TE, Bloom SR, Misiewicz JJ, Silk DBA. Further characterisation of the 'ileal brake' reflex in man - effect of ileal infusion of partial digests of fat, protein, and starch on jejunal motility and release of fat, protein, and starch on jejunal motility and release of 29: 1042-51.

20 Adrian TE, Savage AP, Sagor GR, Allen JM, BacareseHamilton AJ, Tatemoto K, et al. Effect of peptide YY on gastric, pancreatic, and biliary function in humans. Gastroenterology 1985; 89: 494-9.

21 Bilchik AJ, Hines OJ, Adrian TE, McFadden DW, Berger J, Zinner MJ, et al. Peptide YY is a physiological regulator of water and electrolyte absorption in the canine small bowel in vivo. Gastroenterology 1993; 105: 1441-8.

22 Polak JM, Sullivan SN, Bloom SR, Buchan AMJ, Facer P, Brown MR, et al. Neurotensin in human intestine: radioimmunoassay and specific localisation in the $\mathrm{N}$ cell. radioimmunoassay and sp $1977 ; 270: 183-5$.

23 Blackburn AM, Fletcher DR, Bloom SR, Christofides ND, Long RG, Fitzpatrick ML, et al. Effect of neurotensin on gastric function. Lancet 1980; i: 987-9.

24 Polak JM, Buchan AMJ. Motilin immunocytochemical localisation indicates possible molecular heterogeneity or the existence of a motilin family Gastroenterology 1979; 76: 1065-6.

25 Bryant MG, Bloom SR. Distribution of the gut hormones in the primate intestinal tract. Gut 1979; 20: 653-9.

26 Debas HT, Yamagishi T, Dryburgh JR. Motilin enhances gastric emptying of liquids in dogs. Gastroenterology 1977; 73: 777-80.

27 Christofides ND, Modlin IM, Fitzpatrick ML, Bloom SR. Effect of motilin on rate of gastric emptying and gut
hormone release during breakfast. Gastroenterology 1979; hormone rel $903-7$.

28 Christofides ND, Long RG, Fitzpatrick ML, McGregor GP, Bloom SR. Effect of motilin on gastric emptying of glucose and fat in humans. Gastroenterology 1981;80: 456-60.

29 Baak LC, Jansen JBMJ, Biemond I, Lamers CBHW. Weekend treatment with 20 and $40 \mathrm{mg}$ omeprazole: effect on intragastric $\mathrm{pH}$, fasting and postprandial serum gastrin, and serum pepsinogens. Gut 1991; 32: 977-82.

30 Lanzon-Miller S, Pounder RE, Hamilton MR, Ball S, Chronos NAF, Raymond F, et al. Twenty-four hour 
intragastric acidity and plasma gastrin concentration before and during treatment with either ranitidine or omeprazole. Aliment Pharmacol Therap 1987; 1: 239-51.

31 Roberts CJC. Clinical pharmocokinetics of ranitidine. Clin Pharmacokinet 1984; 9: 211-21.

32 Kennedy HJ, Sarson DL, Bloom SR, Truelove SC. Gu hormone responses in subjects with a permanent ileostomy. Digestion 1982; 24: 133-6.

33 Temperley JM, Stagg BH, Wyllie JH. Disappearance of gastrin and pentagastrin in the portal circulation. Gut 1971; 12: $372-6$

34 Becker HD, Reeder DD, Thompson JC. Extraction of circulating endogenous gastrin by the small bowel. Gastroenterology 1973; 65: 903-6.

35 Straus E, Gerson CD, Yalow RS. Hypersecretion of gastrin associated with the short bowel syndrome. associated with the short
Gastroenterology $1974 ; 66: 175-80$.

36 Williams NS, Evans P, King RFGJ. Gastric acid secretion and gastrin production in the short bowel syndrome. Gut 1985; 26: 914-9.

37 Windsor CWO, Fejfar J, Woodward DAK. Gastric secretion after massive small bowel resection. Gut 1969; 10 $779-86$.

38 Bloom SR, Polak JM. Somatostatin. BMF 1987; 295: 288-9.

39 Nightingale JMD, Walker ER, Burnham WR, Farthing MJG Lennard-Jones JE. Octreotide (a somatostatin analogue) improves the quality of life in some patients with a short improves the quality of life in some patients with a shor
intestine. Aliment Pharmacol Therap 1989: 3: 367-73.

40 Sturdevant RAL, Goetz H. Cholecystokinin both stimulates and inhibits human food intake. Nature 1976; 261: 713-5.

41 Muurahainen N, Kissileff HR, Derogatis AJ, Pi-Sunyer FX Effects of cholecystokinin-octapeptide (CCK-8) on food intake and gastric emptying in man. Physiol Behav 1988; 44: 645-9.

42 Lieverse RI, Jansen JBMJ, Masclee AAM, Lamers CBHW. Satiety effects of cholecystokinin in humans. Gastroenterology 1994; 106: 1451-4.

43 Porus RL. Epithelial hyperplasia following massive small bowel resection in man. Gastroenterology 1965; 48: 753-9.

44 Weinstein LD, Shoemaker CP, Hersh T, Wright HK. Enhanced intestinal absorption after small bowel resection in man. Arch Surg 1969; 99: 560-2.

45 Dowling $\mathrm{RH}$, Booth CC. Functional compensation after small bowel resection in man: demonstration by direct measurement. Lancet 1966; ii: 146-7.

46 O'Keefe SJD, Shorter RG, Bennet WM, Haymond MW. Villous hyperplasia is uncommon in patients with massive intestinal resection. Gastroenterology 1992; 102: A231.

47 Gleeson MH, Bloom SR, Polak JM, Henry K, Dowling RH. Endocrine tumour in kidney affecting small bowel structure, motility, and absorptive function. Gut 1971; 12: 773-82.

48 Bloom SR. An enteroglucagon tumour. Gut 1972; 13: $520-3$

49 Rudo ND, Rosenberg IH. Chronic glucagon administration enhances intestinal transport in the rat. Proc Soc Exp Biol Med 1973; 142: 521-5.

50 Miazza BM, Al-Mukhtar MYT, Salmerson M, Ghatei MA Felce-Dachez M, Filali A, et al. Hyperenteroglucagonaemia and small intestinal mucosal growth after colonic perfusion of glucose in rats. Gut 1985; 26: 518-24.

51 de Miguel E, Gomez de Segura IA, Bonet H, RodriguezMontes J A, Mata A. Trophic effects of neurotensin in massive bowel resection in the rat. Dig Dis Sci 1994; 39: 59-64. 